\title{
Effect of IAPP on the proteome of cultured Rin-5F cells
}

\author{
Samaneh Miraee-Nedjad', Paul F. G. Sims ${ }^{1}$, Jean-Marc Schwartz ${ }^{2}$ and Andrew J. Doig ${ }^{3^{*}}$ (D)
}

\begin{abstract}
Background: Islet amyloid polypeptide (IAPP) or amylin deposits can be found in the islets of type 2 diabetes patients. The peptide is suggested to be involved in the etiology of the disease through formation of amyloid deposits and destruction of $\beta$ islet cells, though the underlying molecular events leading from IAPP deposition to $\beta$ cell death are still largely unknown.

Results: We used OFFGEL ${ }^{\text {TM }}$ proteomics to study how IAPP exposure affects the proteome of rat pancreatic insulinoma Rin-5F cells. The OFFGEL ${ }^{\mathrm{TM}}$ methodology is highly effective at generating quantitative data on hundreds of proteins affected by IAPP, with its accuracy confirmed by In Cell Western and Quantitative Real Time PCR results. Combining data on individual proteins identifies pathways and protein complexes affected by IAPP. IAPP disrupts protein synthesis and degradation, and induces oxidative stress. It causes decreases in protein transport and localization. IAPP disrupts the regulation of ubiquitin-dependent protein degradation and increases catabolic processes. IAPP causes decreases in protein transport and localization, and affects the cytoskeleton, DNA repair and oxidative stress,

Conclusions: Results are consistent with a model where IAPP aggregates overwhelm the ability of a cell to degrade proteins via the ubiquitin system. Ultimately this leads to apoptosis. IAPP aggregates may be also toxic to the cell by causing oxidative stress, leading to DNA damage or by decreasing protein transport. The reversal of any of these effects, perhaps by targeting proteins which alter in response to IAPP, may be beneficial for type II diabetes.
\end{abstract}

Keywords: Amylin, Type 2 diabetes, Proteomics, Mass spectrometry, Pathway analysis, Protein-protein interactions

\section{Background}

Type 2 diabetes mellitus, also known as non-insulindependent diabetes mellitus (NIDDM), is the most common type of diabetes with more than 285 million people affected worldwide [1]. The disease is characterised by insulin resistance, impaired regulation of hepatic glucose production and $\beta$ cell dysfunction [2,3]. Type 2 diabetes is an example of a conformational disease, in which amyloid deposition is likely to be a further contributory factor for pathogenesis $[4,5]$. A 37 amino acid peptide, known as islet amyloid polypeptide (IAPP) or amylin, can be isolated from the islets of patients with type 2 diabetes [6]. The normal function of IAPP is to inhibit insulin and glucagon secretion in islets and elsewhere.

\footnotetext{
* Correspondence: andrew.doig@manchester.ac.uk

${ }^{3}$ Division of Neuroscience and Experimental Psychology, School of Biological Sciences, Faculty of Biology, Medicine and Health, The University of Manchester, Manchester M13 9PT, UK

Full list of author information is available at the end of the article
}

It affects satiety regulation and inhibits gastric emptying. The peptide may be involved in the etiology of the disease through formation of amyloid deposits and destruction of $\beta$ islet cells. Further studies have suggested that amyloid deposition contributes to the decreased $\beta$ cell area and increased $\beta$ cell apoptosis in human type 2 diabetes [7-9]. Although these studies are proving to be valuable, the exact cytotoxic action of human IAPP and the underlying molecular events leading from IAPP aggregation to $\beta$ cell death are still largely unknown. The toxic effect of human IAPP is known to involve changes in the expression of a number of genes and proteins [10], though our knowledge of these changes is undoubtedly incomplete. Transcriptional and proteomics studies can therefore facilitate the identification of new genes and gene products that are affected by IAPP.

The development of mass spectrometers with high resolution and high mass accuracy, in combination with different label-free quantitative techniques, has been employed recently to identify new biomarkers for a 
number of conformational diseases, including type 2 diabetes [11-15]. Li and co-workers studied the serum proteins of diabetic and non-diabetic individuals by label-free quantification and shotgun analysis, and detected expression of 147 proteins, from which 67 and 74 proteins were up- and down-regulated, respectively [16]. Pathway analysis techniques linked these proteins to pathways including lipid metabolism and inflammatory response. Proteome analysis of single pancreatic islets by Waanders and co-workers revealed the significant expression of about 140 proteins, with up-regulation of pathways, including TCA cycle and glycolysis [17]. Analysis of label free LC/MS/MS data by Petyuk and co-workers identified the specific expression of 133 proteins in mouse pancreatic islets [18]. The proteins were correlated to a number of complexes and pathways, including the SNARE complex, which is involved in vesicular trafficking and exocytosis, and the TCA cycle. In another study by Hickey et al. the proteomic analysis of the insulin secretory granules was performed [19]. These cytoplasmic organelles of pancreatic $\beta$ cells are responsible for the production and secretion of insulin. Their study identified 51 proteins whose main subcellular locations are cytoplasm, mitochondria and endoplasmic reticulum. Some of the proteins identified in this study were: heat shock proteins and protein disulphide-isomerase (both located in endoplasmic reticulum and involved in protein folding), ATP synthase, pyruvate kinase and citrate synthase (all located in mitochondria and involved in energy metabolism), glyceraldehyde-3phosphate dehydrogenase and aldolase (both located in cytoplasm and involved in energy metabolism) and 14-3-3 zeta isoform (located in cytoplasm and involved in cell signalling). Brunner et al. studied the proteome of the $\beta$ cells insulin secretory granules using insulin-secreting rat INS-1E cells as a model [11]. They identified the expression of 130 proteins with a majority of the proteins associated with the lysosome.

Schvartz and co-workers found 140 proteins enriched in the mature insulin secretory granule fraction, including: insulin, carboxipeptidase E, PC2, Vamps, secretogranins and chromogranins, vacuolar ATPases and G-proteins involved in exocytosis, members of the v-SNARE complex required for secretion in $\beta$-cells, $\mathrm{PC} 1$, a key enzyme for proinsulin processing, and exocytosis proteins Noc2 and RhoG [20]. Lim et al. compared effects of IAPP and $\beta$-amyloid on human neuroblastoma SH-SY5Y cells and found that the major effect of IAPP was to decrease mitochondrial activity [21].

Overall, these previous studies show that IAPP causes increases of: energy metabolism; vesicle trafficking, secretion and endocytosis; chaperones; and inflammation. This suggests that high levels of IAPP cause cellular stress, increased demand for ATP and enhanced cell signalling.
Protein mass spectrometry is a valuable method for identification and quantitative measurements of many proteins from a complex biological mixture. A tandem mass spectrometry based label free approach, combined with OFFGEL ${ }^{\mathrm{ma}}$ fractionation at the protein level [22], was used here to investigate the effects of human IAPP aggregation on the proteome of rat pancreatic insulinoma Rin-5F cells, a cell line widely used in studies of type 2 diabetes. We identified many proteins and pathways whose expressions are affected by IAPP and which are therefore likely to be involved in the pathogenesis of type 2 diabetes.

\section{Results}

\section{Human IAPP significantly reduces Rin-5F cells viability}

To investigate the effect of human IAPP on rat Rin-5F cells, MTT assays were carried out, as they reliably report on cell viability via changes in metabolic activity. The cells were treated initially with different concentrations of IAPP (ranging from $10 \mu \mathrm{M}$ to $1 \mathrm{nM}$ ) for $24 \mathrm{~h}$. Monomers and oligomers of IAPP are known to cross the plasma membrane through both endocytotic and non-endocytotic mechanisms in these cells [23]. The viability of Rin-5F cells was reduced with IAPP concentrations from $10 \mu \mathrm{M}$ to $250 \mathrm{nM}$ (Fig. 1), though there was little change above $5 \mu \mathrm{M}$. Addition of DMSO at the same concentrations had no effect on viability (not shown), showing that loss of viability is solely due to IAPP. $5 \mu \mathrm{M}$ IAPP was therefore used for subsequent work, as the minimal concentration that gives a large change in cell viability. An MTT assay at $5 \mu \mathrm{M}$ was then carried out to identify the optimal time points at which the IAPP cytotoxicity effect had the largest effect on Rin5F cells' viability (Fig. 2). The cells' viability was sharply reduced $2 \mathrm{~h}$ after the addition of IAPP and did not change significantly between $2 \mathrm{~h}$ to $32 \mathrm{~h}$, after which the MTT signal increased slightly. The $5 \mu \mathrm{M}$ IAPP concentration with an exposure time of $24 \mathrm{~h}$ was therefore used for further experiments. In Rin5F cells, $10 \mu \mathrm{M}$ IAPP causes less than $20 \%$ cell death, whilst $20 \mu \mathrm{M}$ is required for complete cell death [24]. This conclusion is not dependent on using MTT, as other toxicity assays (e.g. live/dead) show the same result [25]. A concentration of $10 \mu \mathrm{M}$ is typically used to induce apoptosis [26, 27]. Effects of IAPP on the cells under our conditions will therefore show damaging effects of IAPP before the onset of apoptosis.

\section{OFFGEL ${ }^{\text {TM }}$ electrophoresis successfully separates protein samples from untreated and IAPP treated Rin-5F cells} Prior to OFFGEL ${ }^{\mathrm{Tm}}$ electrophoresis, proteins from untreated (control) and IAPP treated Rin-5F cells were isolated. Total protein concentrations were calculated using a BSA standard curve (not shown) and equal amounts of protein (about $2 \mathrm{mg}$ ) from both samples were fractionated 


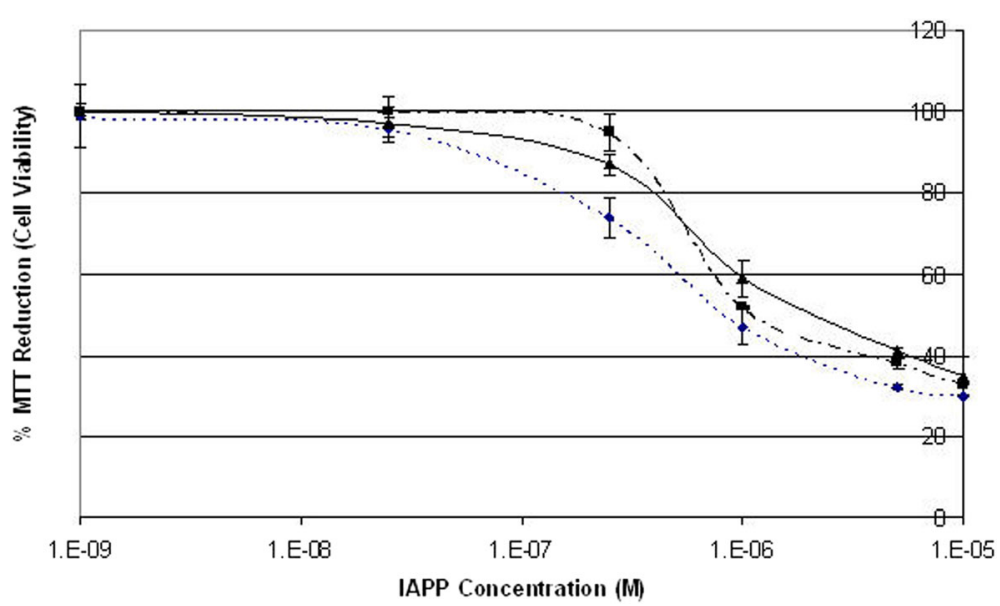

Fig. 1 Effects of IAPP cytotoxicity on Rin-5F cells viability. Results for three independent experiments, where the \% of MTT reduction shows the Rin-5F cells viability. The viability was calculated by measuring the relative absorbance of the formazan product for Rin-5F cells treated with different concentrations of IAPP, compared to the relative absorbance of the formazan product for live and dead cell controls. Vertical bars indicate standard deviations $n=3$

by OFFGEL ${ }^{\mathrm{m}}$ electrophoresis. To determine the fractionation efficiency, one fifth of the protein recovered from each fraction (about $32 \mu \mathrm{g}$ ) was run on an SDS-PAGE gel. The pattern of proteins detected and their band intensities differ significantly between the fractions of each sample, though few differences between untreated and treated Rin-5F cells were apparent by eye (Additional file 1: Figure S1).

Quantitative analysis of cells by label free tandem MS analysis The remaining $80 \%$ of the proteins recovered from each OFFGEL $^{\text {tu }}$ fraction of control and IAPP treated cells were digested into peptides using trypsin and introduced into the tandem mass spectrometer. Table 1 provides a summary of data from three independent experiments, where each experiment was repeated three times. Complete MS results and identified proteins in each OFFGEL ${ }^{\mathrm{mm}}$ fraction are in Additional file 2: Table S1. The pI values of the majority of the identified proteins in each fraction were found to be very close to each other (Additional file 2: Table S1), confirming that the OFFGEL ${ }^{\mathrm{Tu}}$ fractionation of the proteins had been successful. The average $\mathrm{pI}(\mathrm{pH})$ values of each fraction rose steadily from Fraction 1 to 12 and were found to be very close to or within the theoretical $\mathrm{pH}$ ranges expected of fractions. For some fractions, the calculated $\mathrm{pI}$ value differed to some extent from the theoretical $\mathrm{pH}$ range, presumably due to post translational modification, since calculated pI values use the unmodified sequences. The percentages of the average coverage of the proteins identified in each fraction were mostly above $25 \%$, adequate for reliable identification. The number of proteins

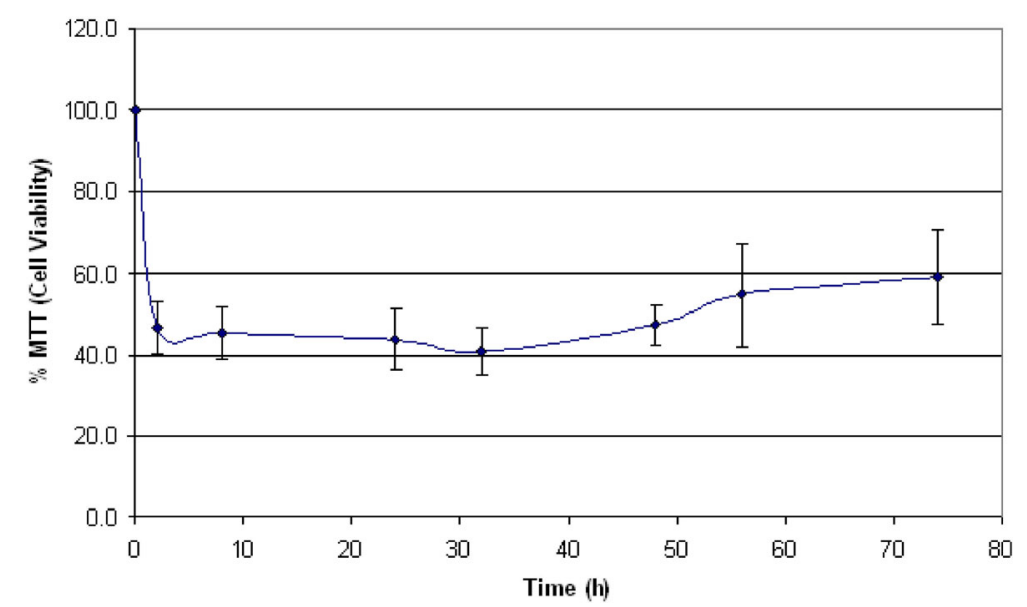

Fig. 2 Effects of IAPP cytotoxicity on Rin-5F cells viability at different time points. Viability was calculated by measuring the relative absorbance of the formazan product for Rin-5F cells treated with $5 \mu \mathrm{M}$ IAPP, compared to the relative absorbance of the formazan product for live and dead cell controls. Vertical bars indicate standard deviations $n=3$ 
Table 1 Proteins Detected in Untreated (Control) and IAPP Treated Rin-5F Cells. Data were obtained from three independent experiments, where each experiment was repeated three times. Data is only reported for proteins detected in all three repeats. F1-F12 are the 12 fractions from OFFGEL ${ }^{\text {TM }}$ electrophoresis, separated by pl. Complete data is in Additional file 1: Table S1

\begin{tabular}{|c|c|c|c|c|c|c|c|c|c|c|c|c|}
\hline Property & $\mathrm{F} 1$ & F2 & F3 & F4 & F5 & F6 & F7 & F8 & F9 & F10 & F11 & $\mathrm{F} 12$ \\
\hline Theoretical pH range & $<3.6$ & $3.6-4.2$ & $4.2-4.7$ & $4.7-5.3$ & $5.3-5.9$ & $5.9-6.5$ & $6.5-7.1$ & $7.1-7.6$ & $7.6-8.2$ & $8.2-8.8$ & $8.8-9.2$ & $>9.2$ \\
\hline \# proteins control Ex1 & 29 & 48 & 48 & 16 & 9 & 4 & 53 & 92 & 54 & 26 & 20 & 19 \\
\hline Mean pl control Ex1 & 4.8 & 4.7 & 4.9 & 5.2 & 5.3 & 5.8 & 6.6 & 7.2 & 7.6 & 8.2 & 8.3 & 8.6 \\
\hline Mean \% protein coverage control Ex1 & 29.8 & 32.9 & 35.9 & 26.1 & 31.3 & 26.6 & 24.7 & 26.2 & 29.5 & 24.7 & 27.2 & 28.1 \\
\hline \# proteins IAPP Ex1 & 33 & 46 & 48 & 53 & 62 & 60 & 70 & 46 & 59 & 15 & 27 & 4 \\
\hline Mean pl IAPP Ex1 & 5.0 & 4.8 & 4.9 & 5.1 & 5.6 & 6.2 & 6.4 & 7.1 & 7.5 & 8.2 & 8.5 & 8.8 \\
\hline Mean \% protein coverage IAPP Ex1 & 27.9 & 33.7 & 29.6 & 29.1 & 25.3 & 28.1 & 26.6 & 25.4 & 27.4 & 18.8 & 31.2 & 27.4 \\
\hline \# proteins control Ex2 & 106 & 189 & 114 & 180 & 190 & 151 & 214 & 238 & 155 & 192 & 169 & 236 \\
\hline Mean pl control Ex2 & 4.9 & 4.9 & 5.1 & 5.4 & 6.0 & 6.4 & 6.8 & 7.0 & 7.6 & 8.0 & 8.1 & 8.5 \\
\hline Mean \% protein coverage control Ex2 & 23.2 & 29.5 & 31.8 & 30.1 & 29.1 & 24.2 & 24.7 & 24.9 & 29.5 & 24.5 & 26 & 25.9 \\
\hline \# proteins IAPP Ex2 & 46 & 131 & 149 & 154 & 152 & 223 & 264 & 270 & 223 & 219 & 145 & 187 \\
\hline Mean pl IAPP Ex2 & 4.8 & 4.8 & 5.1 & 5.3 & 6.0 & 6.6 & 6.7 & 7.1 & 7.7 & 8.0 & 8.6 & 8.9 \\
\hline Mean \% protein coverage IAPP Ex2 & 21.6 & 24.3 & 22.9 & 26.2 & 24.5 & 24.6 & 24.5 & 24.2 & 25.2 & 24.4 & 20.7 & 25.7 \\
\hline \# proteins control Ex3 & 5 & 57 & 52 & 60 & 45 & 64 & 69 & 75 & 30 & 41 & 46 & 0 \\
\hline Mean pl control Ex3 & 4.7 & 4.8 & 5.1 & 5.3 & 5.9 & 6.5 & 6.6 & 7.2 & 7.8 & 7.8 & 8.5 & - \\
\hline Mean \% protein coverage control Ex3 & 24.2 & 32.9 & 29.9 & 23.7 & 22.8 & 26.2 & 25.3 & 25.6 & 27 & 30.8 & 31.4 & - \\
\hline \# proteins IAPP Ex3 & 15 & 33 & 38 & 56 & 50 & 56 & 74 & 53 & 44 & 58 & 27 & 9 \\
\hline Mean pl IAPP Ex3 & 5.0 & 4.8 & 4.9 & 5.3 & 6.0 & 6.6 & 6.5 & 7.0 & 7.8 & 7.9 & 8.4 & 8.9 \\
\hline Mean $\%$ protein coverage IAPP Ex3 & 25.2 & 34.8 & 28.1 & 30.8 & 23.7 & 27.5 & 23.8 & 26.3 & 27.9 & 32.4 & 33.5 & 31.7 \\
\hline
\end{tabular}

identified in experiment 2 was substantially higher than in experiments 1 and 3 for both control and hIAPP treated cells, though it is unclear why. Many of the proteins identified in experiment 2 are not considered further, since we required confirmation of their identification in at least one additional experiment.

\section{Changes in quantitative protein levels in response to IAPP}

To further analyse these data, the quantitative expression patterns of the proteins between the three independent experiments were considered. Our data revealed the common expression of 287 proteins detected in a minimum of two experiments (Additional file 2: Table S1; Additional file 3: Table S2) from which 20 and 5 proteins were found to be significantly down or up-regulated respectively $(p \leq 0.05)$ (Tables 2 and 3). To determine the fold change in the expression level of proteins, the amount of a particular protein in the IAPP treated cells was divided by its corresponding amount in the control cells (IAPP untreated cells). The ratio of every protein was therefore calculated for each experiment and the corresponding ratios of all proteins were then averaged between the three experiments. If a specific protein was not detected in either untreated or IAPP treated samples, the missing value was replaced by the smallest amount that was potentially detected by the machine. In these experiments, the lowest value detected in any sample was 0.1 femtomole for an unknown $35 \mathrm{kD}$ protein (IPI00948374). Proteins were considered to be either up regulated or down-regulated if this ratio was significantly greater than or less than 1 , respectively.

\section{Down-regulated proteins}

Some of the proteins we identified as showing significant responses to IAPP have previously been reported to be linked to type II diabetes:

Heterogeneous nuclear ribonucleoprotein $\mathrm{F}$ has been shown to protect against hypertension, renal hypertrophy, and interstitial fibrosis in a diabetic mouse model [28]. Its down-regulation by IAPP may thus lead to diabetes.

Estrogen hormones, such as estradiol-17b, stimulate creatine kinase activity, generating phosphocreatine, a high energy store for brain and muscle. Diabetic rats show a decreased response to estradiol-17b [29]. Similarly, we see a decrease in creatine kinase levels in response to IAPP.

Oxidative stress is an important component of diabetes [30]. Thioredoxin dependent peroxide reductase is used to alleviate oxidative stress by detoxifying reactive oxygen species. Peroxiredoxin 1 similarly reduces hydrogen peroxide. We see that IAPP down-regulates both mitochondrial thioredoxin dependent peroxide reductase and peroxiredoxin 1, thus potentially explaining how oxidative stress is increased in type 2 diabetes. Similarly, loss of functional 14-3-3 protein caused downregulation of thioredoxin reductase in a diabetic mouse model, as 
Table 2 Significantly Down-Regulated Proteins in IAPP Treated Rin-5F Cells. The data were obtained from three independent experiments. To obtain the protein abundance ratio the amount of each protein in the IAPP treated cells was divided by its corresponding amount in the control cells (IAPP untreated cells). The corresponding ratios of all proteins were then averaged between the three experiments. If a specific protein was expressed in either untreated or IAPP treated samples, the missing value was replaced by the smallest amount that was potentially detected by the machine ( 0.1 femtomole). Differences between IAPP treated and un-treated expression levels are considered to be significant if $p \leq 0.05$. To determine the $p$ value two-tailed Student's t-test was performed, comparing the three individual control amounts with the three corresponding treated samples

\begin{tabular}{|c|c|c|c|c|c|}
\hline Accession \# & UniProt Id & Description & $\begin{array}{l}\text { Mean ratio } \\
\text { (IAPP treated/control) }\end{array}$ & SD & $p$ Value \\
\hline IPI00471525 & Q68FR9/F1LP72 & Uncharacterized protein & 0.054 & 0.076 & 0.048 \\
\hline IPI00231968 & Q5U362 & Annexin A4 isoform CRA a & 0.097 & 0.059 & 0.043 \\
\hline IPI00210357 & Q794E4 & Heterogeneous nuclear ribonucleoprotein F & 0.126 & 0.040 & 0.048 \\
\hline IPI00470288 & Q9EQS0/P07335 & Creatine kinase B type & 0.143 & 0.027 & $<0.001$ \\
\hline IPI00208215 & Q9Z0V6 & Thioredoxin dependent peroxide reductase mitochondrial & 0.221 & 0.009 & 0.034 \\
\hline IPI00387868 & O88600/F1LRV4 & Heat shock 70 kDa protein 4 & 0.273 & 0.021 & 0.048 \\
\hline IPI00211779 & Q63716 & Peroxiredoxin 1 & 0.277 & 0.001 & 0.032 \\
\hline IPI00197696 & Q0QF43/P04636 & Malate dehydrogenase mitochondrial & 0.291 & 0.104 & 0.013 \\
\hline IPI00201333 & D4A0W9 & Uncharacterized protein & 0.388 & 0.139 & 0.050 \\
\hline IPI00190559 & Q9EQX9 & Ubiquitin conjugating enzyme E2 N & 0.453 & 0.100 & 0.021 \\
\hline IPI00324893 & P63102 & 1433 protein zeta delta & 0.558 & 0.088 & 0.001 \\
\hline IPI00200147 & P19945 & 605 acidic ribosomal protein P0 & 0.678 & 0.057 & 0.043 \\
\hline IPI00365935 & P83868/B2GV92 & Prostaglandin E synthase 3 & 0.692 & 0.070 & 0.005 \\
\hline IPI00200861 & P04961 & Proliferating cell nuclear antigen & 0.877 & 0.315 & 0.005 \\
\hline IPI00189925 & P54921 & Alpha soluble NSF attachment protein & 0.005 & 1.865 & 0.038 \\
\hline IPI00189989 & B2RYK3/P18297 & Sepiapterin reductase & 0.006 & 1.089 & 0.027 \\
\hline IPI00363925 & B5DEH4 & Uap111 protein & 0.014 & 0.234 & 0.015 \\
\hline IPI00365423 & O35511/Q5X134 & Protein phosphatase 2 Formerly $2 \mathrm{~A}$ regulatory subunit $\mathrm{A}$ alpha isoform & 0.003 & 4.101 & 0.050 \\
\hline IPI00370456 & Q4FZT9 & 265 proteasome non ATPase regulatory subunit 2 & 0.007 & 0.491 & 0.016 \\
\hline IPI00768299 & B2GV73/F1LRL8 & Actin related protein 23 complex subunit 3 Predicted isoform CRA b & 0.010 & 0.798 & 0.037 \\
\hline
\end{tabular}

well as other adverse effects, such as increases in myocardial apoptosis, cardiac hypertrophy, and fibrosis [31].

Levels of the $70 \mathrm{kDa}$ heat shock protein increase in serum T2D patients [32], presumably due to its cytoprotective chaperone effects. Reduction of chaperone levels by IAPP may thus lead to cytotoxicity.
Diabetes has been shown to lead to alterations in post-translational methylation, phosphorylation and nitration in protein phosphatase 2, resulting in its hyperactivation [33]. Alpha soluble NSF attachment protein is an indispensable component of membrane fusion machinery, required for vesicular transport between the endoplasmic reticulum

Table 3 Significantly Up-Regulated Proteins in IAPP Treated Rin-5F Cells. The data were obtained from three independent experiments. To obtain the protein abundance ratio the amount of each protein in the IAPP treated cells was divided by its corresponding amount in the control cells (IAPP untreated cells). The corresponding ratios of all proteins were then averaged between the three experiments. If a specific protein was expressed in either untreated or IAPP treated samples, the missing value was replaced by the smallest amount that was potentially detected by the machine ( 0.1 femtomole). Differences between IAPP treated and un-treated expression levels are considered to be significant if $p \leq 0.05$. To determine the $p$ value two-tailed Student's ttest was performed, comparing the three individual control amounts with the three corresponding treated samples

\begin{tabular}{|c|c|c|c|c|c|}
\hline Accession \# & UniProt Id & Description & Mean ratio (IAPP treated/control) & SD & $p$ Value \\
\hline IPI00194045 & Q0QER8/P41562 & Isocitrate dehydrogenase NADP cytoplasmic & 175 & 6 & 0.033 \\
\hline IPI00204532 & D3ZYT1 & Ubiquitin carboxyl terminal hydrolase & 88 & 3 & 0.043 \\
\hline IPI00372214 & Q4V7C6/D4A7l4 & GMP synthase glutamine hydrolyzing & 116 & 0.9 & 0.035 \\
\hline IPI00421995 & Q6MG61 & Chloride intracellular channel protein 1 & 302 & 1 & 0.015 \\
\hline IPI00209115 & Q6IRH6 & Solute carrier family 25 Mitochondrial carrier & 87 & 0.6 & 0.031 \\
\hline
\end{tabular}


and the Golgi apparatus. Alterations in its expression are associated with type 2 diabetes [34]. Diabetic rats were shown to have lower levels of Proliferating cell nuclear antigen, a marker of cell proliferation, in rat testicular tissue [35].

Ubiquitin-conjugating enzyme E2E2 (UBE2E2) plays an important role in the synthesis and secretion of insulin. Mutations in UBE2E2 increase risk for type 2 diabetes [36]. 60S acidic ribosomal protein P0 is downregulated, suggesting a decrease in protein synthesis.

\section{Up-regulated proteins}

Reduced cytoplasmic isocitrate dehydrogenase expression in rat insulin secreting cells and isolated rat islet ß-cells resulted in enhanced glucose-induced insulin secretion [37]. The deubiquitining enzyme ubiquitin carboxyl terminal hydrolase is upregulated, again consistent with disruption of protein degradation.

Quantitative RT-PCR miRNA screening in diabetic mice found alteration in the expression of a regulator of the inner mitochondrial membrane phosphate transporter, solute carrier family 25 member 3 (Slc25a3). This provides inorganic phosphate to the mitochondrial matrix and is essential for ATP production [38].

In addition to confirming the roles of the above proteins in type 2 diabetes, we can also report the involvement of various other proteins (Tables 2 and 3).

\section{Verification of protein expression}

In Cell Western analysis and RT-PCR quantitative techniques were used to confirm the expression of representative proteins identified by tandem MS/MS at the translational and transcriptional levels, respectively. To carry out the In Cell Western analysis, cells were stained for the expression of 6 proteins (peroxiredoxin1, Superoxide dismutase $\mathrm{Cu} \mathrm{Zn}$, Protein disulfide isomerase A3, PCNA, Elongation factor 2 and 14-3 -3 protein zeta delta), chosen as they show high, though varying, levels of expression (Additional file 2: Table S1) and have available antibodies. Protein expression was observed in both cultures (Fig. 3), and their changes in levels were consistent with the mass spectrometry data. For example, the expression of peroxiredoxin 1 and disulfide isomerase A3 is shown to be reduced and increased, respectively, upon IAPP treatment by both techniques.

RT-PCR was also carried out to further confirm the proteomics data, studying the same proteins as in the Western experiment. Rin-5F cells were treated with IAPP for $24 \mathrm{~h}$. RNA was extracted from cells and reverse transcribed before analysis by RT-PCR. Data from three independent experiments showed similar expression of mRNA for all 6 proteins in untreated and IAPP treated cultures to mass spectrometry data (Fig. 4). Perfect agreement between RT-PCR and proteomics data is highly unlikely, since protein abundance is affected by translation and degradation rates, not just expression. Nevertheless, these Western and RT-PCR data do confirm the reliability of our mass spectrometry results.

\section{Data analysis}

To obtain more systematic information about these data, several bioinformatics approaches, including network analysis techniques, pathway analysis and protein complex analysis, were used. This information provides more insight into the function of the proteins, with the aim of facilitating the identification of novel proteins and pathways that might be involved in the pathogenesis of type 2 diabetes.

\section{Pathway analysis of IAPP responsive proteins}

To demonstrate the biological significance of the IAPP responsive proteins, both sets of down- and up-regulated proteins were studied for the Gene Ontology biological process annotations. The number of up-regulated proteins was too small to have significant GO terms associated with it. Four annotations were significant for the down-regulated protein set, namely response to oxidative stress, regulation of cell death, hydrogen peroxide catabolic process and positive regulation of cell repair (Table 4).

Analysis using DAVID [39] of down-regulated proteins has further identified several pathways for these proteins. Three significantly down-regulated proteins (P04636, Q9EQS0, B5DEH4) are within the KEGG pathway "rno01130:Biosynthesis of antibiotics". Other pathways that contain down-regulated proteins are listed in Table 5.

\section{Analysis of protein-protein interactions}

To further evaluate the effect of IAPP on the proteomic profile of the Rin-5F cells, the total set of 287 proteins were analysed for their protein interacting abilities using the STRING database [40]. Out of the 287 target proteins, 156 proteins were found to interact with at least one other protein from the list (Additional file 4: Table S3). These data were used to construct a network for the protein-protein interactions using Cytoscape [41] (Additional file 5: Figure S2). To analyse the proteins within this network, network parameters, such as degree (number of connections between nodes), closeness and betweenness centrality were determined. While closeness centrality determines the centrality of a node that lies inside a particular community (node neighbours from the same group), the betweenness centrality determines the centrality of a node that lies between different communities (node neighbours from different groups) and acts as a bridge to connect these groups together. In other words, the closeness centrality measures the speed of information transfer from a given node to others in a network, while the betweenness centrality indicates how much control a particular node in a network possesses over the interaction of another node in the same network [42].Analysis of the network parameter data for all of the IAPP responsive and un-responsive 


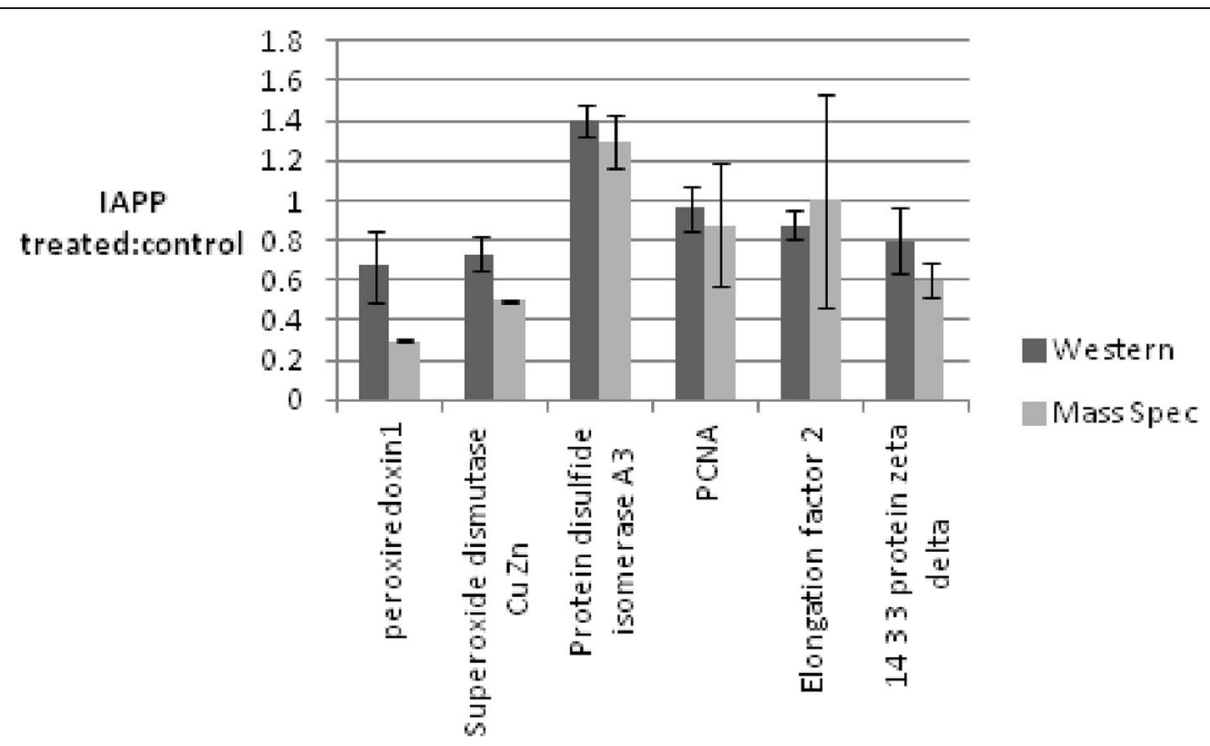

Fig. 3 Quantitative analysis of the data obtained from the In Cell Western experiment. The amount of each protein (peroxiredoxin1, Superoxide dismutase Cu Zn, Protein disulfide isomerase A3, PCNA, Elongation factor 2 and 14-3-3 protein zeta delta) expressed in IAPP treated cells was divided by its amount in the control cells. The experiment was repeated three times and the average ratio for each protein was then compared to its corresponding average ratio obtained from the mass spectrometry data. Vertical bars indicate standard deviations $n=3$

proteins revealed that the higher degree hub proteins (such as glyceraldehyde 3-phosphate dehydrogenase, ubiquitin A-52 residue ribosomal protein, ATP synthase alpha Subunit 1 and citrate synthase) are positioned mostly in the centre of the protein-protein interaction network. Table 6 summarizes the network parameters data for the top 20 hub proteins with the highest values of degree, closeness and betweenness centrality. As seen in this table, the majority of the proteins (such as triosephosphate isomerase 1 , glyceraldehyde-3-phosphate dehydrogenase and ATP synthase) are found in at least two out of the three categories and possess high values for network properties. While many of these proteins are involved in metabolic pathways (such as glutamate dehydrogenase 1 and serine hydroxymethyltransferase 2), others

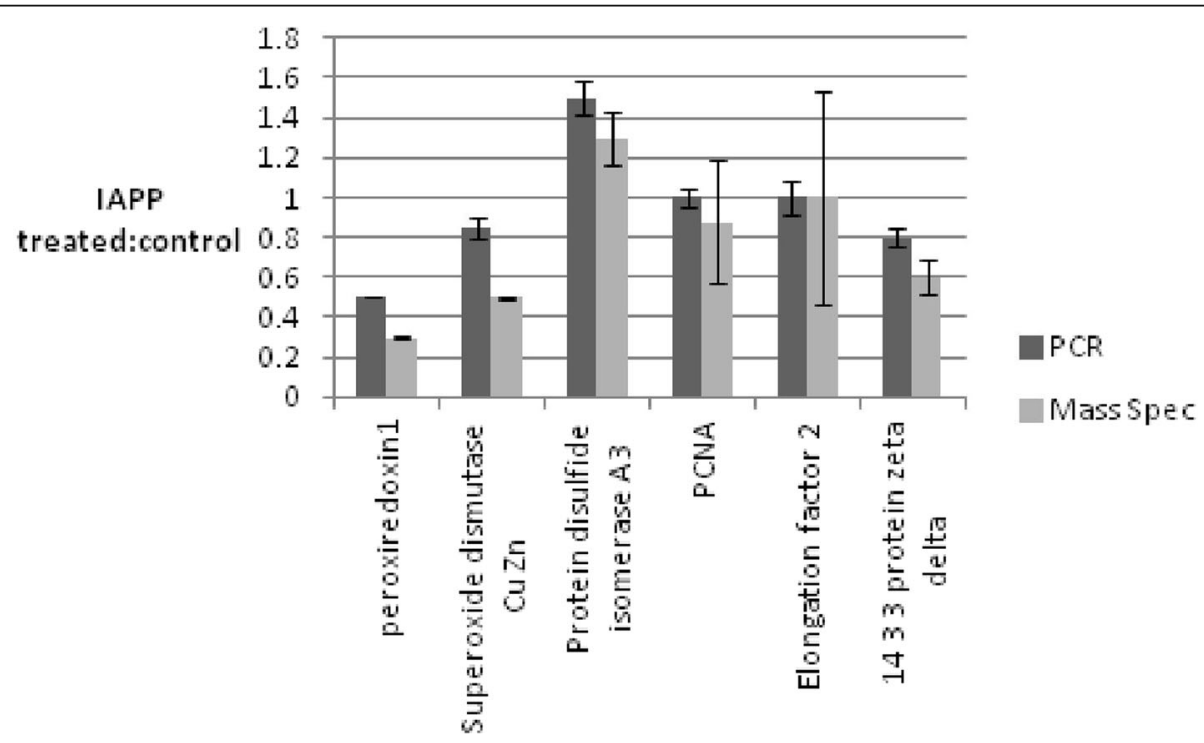

Fig. 4 Quantitative analysis of the data obtained from the RT-PCR experiment. The amount of each protein (peroxiredoxin1, Superoxide dismutase Cu Zn, Protein disulfide isomerase A3, PCNA, Elongation factor 2 and 14-3-3 protein zeta delta) was initially normalized against the expression level of the GAPDH housekeeping gene. To obtain the ratio of expression, the amount of each protein expressed in IAPP treated cells was divided by its corresponding amounts in the untreated cells. The experiment was repeated three times. The average ratio for each protein was then compared to its corresponding average ratio obtained from the mass spectrometry data. Vertical bars indicate standard deviations $n=3$ 
Table 4 Gene Ontology Analysis for Down-Regulated Proteins. Information is generated using the Gene Ontology analysis tool in DAVID

\begin{tabular}{llll}
\hline Gene Ontology & Proteins & Fold Enrichment & $p$-Value \\
\hline GO:0006979: response to oxidative stress & P04961, Q9Z0V6, Q63716 & 18 & 0.011 \\
GO:0010941: regulation of cell death & P63102, Q68FR9 & 125 & 0.015 \\
GO:0042744: hydrogen peroxide catabolic process & Q9Z0V6, Q63716 & 97 & 0.019 \\
GO:0045739: positive regulation of DNA repair & P04961, Q9EQX9 & 58 & 0.032 \\
\hline
\end{tabular}

(such as ATP synthase alpha and beta subunits along with ribosomal protein S27a) are involved in other amyloid diseases pathways including Parkinson's disease, Alzheimer's disease and Huntington's disease. Glycolysis (triosephosphate isomerase 1 and phosphoglycerate kinase 1), citrate cycle (citrate synthase and malate dehydrogenase 2) and type II diabetes mellitus (pyruvate kinase) were among the other pathways identified for these proteins.

Most of the identified hub proteins in the network were unresponsive to the effect of IAPP. As seen in Table 7, many of the up and down regulated proteins in this network are not strong hubs and they are not highly connected to other proteins in the network. In other words, the analysis of the network parameter data revealed a very weak correlation between the fold change and connectivity or centrality. This finding is in agreement with previous reports which showed that about $78 \%$ of genes/proteins implicated in diseases are found to be non-essential. As hub proteins are more likely to be encoded by essential genes, disease genes do not tend to correlate with hubs $[43,44]$. Our data suggests that there is only a weak tendency for IAPP responsive proteins to be associated with hubs.

The effect of IAPP on the protein complexes was also investigated using the MIPS database (Mammalian Protein-Protein Interaction Database) [45]. Proteins up

Table 5 Pathways Identified for Down-Regulated Proteins

\begin{tabular}{|c|c|c|}
\hline Protein ID & Protein Name & Pathway \\
\hline P54921 & NSF attachment protein alpha(Napa) & Synaptic vesicle cycle \\
\hline B5DEH4 & $\begin{array}{l}\text { UDP-N-acetylglucosamine pyrophosphorylase } 1 \\
\text { like } 1 \text { (Uap1|1) }\end{array}$ & $\begin{array}{l}\text { Amino sugar and nucleotide sugar metabolism, Metabolic pathways, } \\
\text { Biosynthesis of antibiotics }\end{array}$ \\
\hline B2GV73 & $\begin{array}{l}\text { actin related protein } 2 / 3 \text { complex, } \\
\text { subunit } 3(\operatorname{Arpc} 3)\end{array}$ & $\begin{array}{l}\text { Endocytosis, Fc gamma R-mediated phagocytosis, Regulation of actin } \\
\text { cytoskeleton, Bacterial invasion of epithelial cells, Salmonella infection. }\end{array}$ \\
\hline P07335 & creatine kinase $\mathrm{B}(\mathrm{Ckb})$ & Arginine and proline metabolism, Metabolic pathways \\
\hline Q68FR9 & $\begin{array}{l}\text { eukaryotic translation elongation factor } 1 \\
\text { delta(Eef1d) }\end{array}$ & Herpes simplex infection \\
\hline O88600, F1LRV4 & heat shock protein family A member 4(Hspa4) & Antigen processing and presentation \\
\hline P04636, Q0QF43 & malate dehydrogenase 2(Mdh2) & $\begin{array}{l}\text { Citrate cycle (TCA cycle), Cysteine and methionine metabolism, Pyruvate } \\
\text { metabolism, Glyoxylate and dicarboxylate metabolism, Metabolic pathways, } \\
\text { Biosynthesis of antibiotics, Carbon metabolism }\end{array}$ \\
\hline Q63716 & peroxiredoxin 1(Prdx1) & Peroxisome \\
\hline P04961 & proliferating cell nuclear antigen(Pcna) & $\begin{array}{l}\text { DNA replication, Base excision repair, Nucleotide excision repair, } \\
\text { Mismatch repair, Cell cycle, Hepatitis } B, H T L V-I \text { infection }\end{array}$ \\
\hline B2GV92, P83868 & prostaglandin E synthase 3(Ptges3) & Arachidonic acid metabolism, Metabolic pathways \\
\hline Q4FZT9 & proteasome 265 subunit, non-ATPase 2(Psmd2) & Proteasome, Epstein-Barr virus infection \\
\hline Q5X134 & $\begin{array}{l}\text { protein phosphatase } 2 \text { scaffold subunit A } \\
\text { alpha(Ppp2r1a) }\end{array}$ & $\begin{array}{l}\text { mRNA surveillance pathway, Sphingolipid signalling pathway, Oocyte meiosis, } \\
\text { PI3K-Akt signalling pathway, AMPK signalling pathway, Adrenergic signalling in } \\
\text { cardiomyocytes, TGF-beta signalling pathway, Hippo signalling pathway, Tight } \\
\text { junction, Dopaminergic synapse, Long-term depression, Chagas disease } \\
\text { (American trypanosomiasis), Hepatitis C }\end{array}$ \\
\hline P19945 & ribosomal protein lateral stalk subunit PO(Rplp0) & Ribosome \\
\hline P18297, B2RYK3 & $\begin{array}{l}\text { sepiapterin reductase } \\
\text { (7,8-dihydrobiopterin:NADP+ oxidoreductase)(Spr) }\end{array}$ & Folate biosynthesis, Metabolic pathways \\
\hline Q9EQS0 & transaldolase 1(Taldo1) & $\begin{array}{l}\text { Pentose phosphate pathway, Metabolic pathways, Biosynthesis of antibiotics, } \\
\text { Carbon metabolism, Biosynthesis of amino acids }\end{array}$ \\
\hline P63102 & $\begin{array}{l}\text { tyrosine 3-monooxygenase/tryptophan } \\
\text { 5-monooxygenase activation protein, zeta(Ywhaz) }\end{array}$ & $\begin{array}{l}\text { Cell cycle, Oocyte meiosis, PI3K-Akt signalling pathway, Hippo signalling } \\
\text { pathway, Hepatitis B, Epstein-Barr virus infection, Viral carcinogenesis }\end{array}$ \\
\hline Q9EQX9 & ubiquitin-conjugating enzyme E2N(Ube2n) & Ubiquitin mediated proteolysis \\
\hline
\end{tabular}


Table 6 Twenty Top Proteins for Protein-Protein Interaction Network Parameter Terms (network degree, closeness centrality and betweenness centrality). Proteins with a closeness centrality of 1.0 were excluded as they correspond to isolated protein pairs

\begin{tabular}{|c|c|c|c|c|c|c|c|c|c|c|c|}
\hline Protein & Accession \# & Degree & $\begin{array}{l}\text { Fold } \\
\text { change }\end{array}$ & Protein & Accession \# & $\begin{array}{l}\text { Closeness } \\
\text { centrality }\end{array}$ & Fold change & Protein & Accession \# & $\begin{array}{l}\text { Between-ness } \\
\text { centrality }\end{array}$ & Fold change \\
\hline Tpi1 & IPI00231767 & 47 & 1.8 & Gapdh & IPI00555252 & 0.481 & 0.34 & Gapdh & IPI00555252 & 0.135 & 0.34 \\
\hline Mdh2 & IPI00197696 & 38 & 0.29 & Tpi1 & IPI00231767 & 0.463 & 1.5 & Pcna & IPI00200861 & 0.127 & 0.89 \\
\hline Sod2 & IPI00211593 & 38 & 1.1 & Alb & IPI00191737 & 0.460 & 1.3 & Actb & IPI00189819 & 0.0683 & 0.94 \\
\hline Gapdh & IPI00555252 & 37 & 0.34 & Pcna & IPI00200861 & 0.444 & 0.88 & Alb & IPI00191737 & 0.0645 & 1.3 \\
\hline Cs & IPI00206977 & 35 & 1.1 & Atp5a1 & IPI00396910 & 0.441 & 1.1 & Eef2 & IPI00203214 & 0.0574 & 1.1 \\
\hline Atp5a1 & IPI00396910 & 34 & 1.1 & Atp5b & IPI00551812 & 0.440 & 0.44 & Atp5a1 & IPI00396910 & 0.0522 & 1.1 \\
\hline Atp5b & IPI00551812 & 33 & 0.44 & Pgk1 & IPI00231426 & 0.438 & 0.92 & Tpi1 & IPI00231767 & 0.0506 & 1.5 \\
\hline Pkm2 & IPI00231929 & 31 & 0.59 & Eef2 & IPI00203214 & 0.436 & 1.1 & $\mathrm{Cfl} 1$ & IPI00327144 & 0.0387 & 1.4 \\
\hline Shmt2 & IPI00195109 & 30 & 1.2 & Shmt2 & IPI00195109 & 0.436 & 1.2 & Glud1 & IPI00324633 & 0.0383 & 2.1 \\
\hline Glud1 & IPI00324633 & 30 & 2.1 & Cs & IPI00206977 & 0.435 & 1.1 & Gnb2l1 & IPI00231134 & 0.0372 & 1.5 \\
\hline Dld & IPI00365545 & 30 & 1.9 & Pkm2 & IPI00231929 & 0.431 & 0.59 & Gmps & IPI00372214 & 0.0371 & 120 \\
\hline Alb & IPI00191737 & 29 & 1.3 & Dhfr & IPI00200419 & 0.429 & 1.2 & $\operatorname{Rad} 23 b$ & IPI00210495 & 0.0359 & 0.96 \\
\hline Pgk1 & IPI00231426 & 27 & 0.92 & Mdh2 & IPI00197696 & 0.424 & 0.29 & Stip1 & IPI00213013 & 0.0343 & 2.0 \\
\hline Pcna & IPI00200861 & 25 & 0.88 & Actb & IPI00189819 & 0.423 & 0.94 & Mdh2 & IPI00197696 & 0.0332 & 0.29 \\
\hline Gmps & IPI00372214 & 25 & 120 & Hspa4 & IPI00387868 & 0.423 & 0.27 & Tubb5 & IPI00197579 & 0.0317 & 0.15 \\
\hline Eef2 & IPI00203214 & 24 & 1.1 & Sod2 & IPI00211593 & 0.422 & 1.1 & Shmt2 & IPI00195109 & 0.0303 & 1.2 \\
\hline Mdh1 & IPI00198717 & 24 & 6.0 & Gmps & IPI00372214 & 0.419 & 120 & Eif5a & IPI00211216 & 0.0286 & 0.34 \\
\hline Gnb2l1 & IPI00231134 & 23 & 1.5 & Gnb2|1 & IPI00231134 & 0.413 & 1.5 & Dars & IPI00206224 & 0.0257 & 1.1 \\
\hline Sod1 & IPI00231643 & 23 & 0.52 & Txn1 & IPI00216298 & 0.411 & 29 & Aprt & IPI00950965 & 0.0256 & 0.016 \\
\hline Txn1 & IPI00231368 & 23 & 29 & Sod1 & IPI00231643 & 0.409 & 0.52 & Ywhaz & IPI00324893 & 0.0250 & 0.56 \\
\hline
\end{tabular}

or down-regulated by IAPP treatment were submitted to MIPS. Six protein complexes were down-regulated and none were up-regulated (Table 8). To determine the fold changes in the expression level of protein complexes the number of affected subunits within each complex in the IAPP treated cells was divided by its corresponding amount in the control cells. The Alpha soluble NSF attachment protein was found in four complexes, three of which are SNARE complexes, while two proteins were found in the CLIC4 complex. The SNARE complex is involved in vesicular trafficking and exocytosis, and the TCA cycle, and has been linked to type 2 diabetes by several other groups $[18,20]$. CLIC4 is a chloride channel involved in stabilisation of cell membrane potential,

Table 7 Network Parameter Data (Degree, Closeness Centrality and Betweenness Centrality) for the Up- and Down-Regulated Proteins in the Protein-Protein Interaction Network

\begin{tabular}{lllll}
\hline Protein Ids & Fold Change & Closeness Centrality & Degree & Betweenness Centrality \\
\hline Mdh2 / P04636 & 0.29 & 0.424 & 38 & 0.0332 \\
Hspa4 / F1LRV4 & 0.27 & 0.423 & 16 & 0.0224 \\
Ywhaz / P63102 & 0.56 & 0.369 & 10 & 0.0251 \\
Arbp / P19945 & 0.68 & 0.388 & 13 & 0.0142 \\
Ube2n / Q9EQX9 & 0.45 & 0.248 & 1 & 0.0 \\
Slc25a3 / Q6IRH6 & 87 & 0.364 & 11 & 0.0011 \\
Prdx3 / Q9Z0V6 & 0.22 & 0.321 & 5 & 0.0014 \\
Idh1 / P41562 & 175 & 0.338 & 0.0 \\
Ppp2r1a / O35511 & 0.003 & 0.350 & 7 & 0.0093 \\
Ptges3 / B2GV92 & 0.69 & 0.330 & 3 & 0.0003 \\
Eef1d / F1LP72 & 0.054 & 0.312 & 4 & 0.0 \\
Pcna / P04961 & 0.88 & 0.444 & 25 & 0.127 \\
\hline
\end{tabular}


Table 8 Protein Complexes Identified for Down-Regulated Proteins using MIPS

\begin{tabular}{|c|c|c|c|c|c|}
\hline Complex name & Protein Id & Description & $\begin{array}{l}\text { Average ratio of subunits within } \\
\text { the complex (IAPP/Control }\end{array}$ & $\begin{array}{l}\text { Average standard } \\
\text { deviations }\end{array}$ & Mean $p$-Value \\
\hline CLIC4 complex & P63102 & 1433 protein zeta delta & 0.35 & 0.06 & 0.001 \\
\hline CLIC4 complex & P07335 & Creatine kinase B type & & & \\
\hline SNARE complex Snap25 & P54921 & Alpha soluble NSF attachment protein & 0.0045 & 1.87 & 0.038 \\
\hline SNARE complex Stx1a & P54921 & Alpha soluble NSF attachment protein & 0.0045 & 1.87 & 0.038 \\
\hline SNARE complex Stx4 & P54921 & Alpha soluble NSF attachment protein & 0.0045 & 1.87 & 0.038 \\
\hline Nsf-Stx1a-Napa complex & P54921 & Alpha soluble NSF attachment protein & 0.0045 & 1.87 & 0.038 \\
\hline
\end{tabular}

transport, maintenance of intracellular $\mathrm{pH}$ and regulation of cell volume.

\section{Discussion}

Our data analysis has identified pathways and protein complexes that have been affected by toxic (though not lethal) levels of IAPP to Rin-5F cells and which may be involved in the pathogenesis of type II diabetes. IAPP added to Rin-5F cells provides a simpler, more homogeneous model than, say, post-mortem islets cells from a diabetic patient, and allow us to study early cellular events caused by a toxic peptide. The strongest effect of the addition of IAPP is disruption of protein synthesis and degradation, together with induction of oxidative stress. This agrees well with the work of Casas et al., who found that impairment of the ubiquitin-proteasome pathway is implicated in ER stress-mediated pancreatic $\beta$-cell apoptosis [46]. Oxidative stress is known to be an important component of diabetes [30] IAPP also induces decreases in protein transport and localization. Most of the pathways that we find to be affected differ from previous proteomic work on IAPP, though we do see effects on TCA Cycle, heat shock and cell signaling.

\section{Conclusions}

The OFFGEL ${ }^{\mathrm{Tm}} / \mathrm{HI} 3$ methodology is highly effective at generating quantitative data on hundreds of proteins affected by toxic IAPP. Its accuracy is confirmed by In Cell Western and Quantitative Real Time PCR results. Our results are consistent with a model where IAPP aggregates overwhelm the ability of a cell to degrade proteins via the ubiquitin system, leading to DNA damage, decreases in protein transport and ultimately apoptosis.

\section{Methods}

\section{Cell culture}

The rat pancreatic insulinoma Rin-5F cell line was purchased from the European Collection of Cell Cultures (ECACC, Wiltshire, UK). The cells were cultured in RPMI 1640 medium supplemented with 10\% (v/v) Foetal Bovine Serum (FBS) (PAA Laboratories, UK), and $2 \mathrm{mM}$ Glutamine. The cells were maintained in a $5.0 \% \mathrm{CO}_{2}$ humidified atmosphere at $37^{\circ} \mathrm{C}$.

\section{hIAPP cytotoxicity}

hIAPP was purchased from Bachem (Germany). The powder was dissolved in high-grade 1,1,1,3,3,3-hexafluoroisopropanol (HFIP) (Sigma, UK) to a stock concentration of $1 \mathrm{mM}$. Reconstituted hIAPP was snap-frozen in liquid nitrogen and freeze dried to remove HFIP. Freeze dried hIAPP was kept at $-20{ }^{\circ} \mathrm{C}$ and dissolved in dimethyl sulfoxide (DMSO) (Sigma, UK) to the required concentration before each experiment. The cytotoxicity of IAPP on Rin-5F cells was assessed by the MTT assay [47] according to the manufacturer's protocol (Sigma, UK). The cells were initially plated in triplicate at a density of $2.5 \times 10^{4}$ cells/well in 96 well plates in Optimal media (Invitrogen, UK) supplemented with 5\% (v/v) Foetal Bovine Serum (FBS) (PAA Laboratories, UK), $2 \mathrm{mM}$ Glutamine and non-essential amino acids (PAA Laboratories, UK). After overnight growth, IAPP was added to the cells to give the required concentration. Plates were further incubated for the times indicated in a $5 \%(\mathrm{v} / \mathrm{v}) \mathrm{CO}_{2}$ and $95 \%(\mathrm{v} / \mathrm{v})$ air incubator. For the dead cell controls, 0.5\% (v/v) Triton X-100 (Sigma-UK) was added to the wells. Live cell controls contained Rin-5F cells only. The results of the MTT assays are expressed as percentage of MTT reduction (percentage of cell viability) and calculated as: \% MTT reduction $(\%$ cell viability $)=\{(\mathrm{C}-\mathrm{A}) \div(\mathrm{B}-\mathrm{A})\} \times 100 \%$, where $\mathrm{C}$ is the mean absorbance of the cells treated with IAPP $(n=3), \mathrm{A}$ is the mean absorbance of the dead cell control samples $(n=3)$ and $\mathrm{B}$ is the mean absorbance of the live controls samples $(n=3)$.

\section{Protein fractionation and identification}

A urea/thiourea extraction was utilized to extract the proteins from 70 to $80 \%$ confluent T75 flasks (about $10^{7}$ cells) of untreated or $5 \mu \mathrm{M}$ IAPP treated Rin-5F cells. Rin-5F cell pellets were extracted in $1 \mathrm{ml}$ of lysis buffer containing 9.5 M urea, $2 \mathrm{M}$ thiourea, $4 \%(w / v)$ CHAPS, $1 \%(\mathrm{w} / \mathrm{v})$ DTT, $2.5 \mathrm{mM}$ EDTA and $2.5 \mathrm{mM}$ EGTA (all from Sigma-UK). Samples were vortexed 5 times for $10 \mathrm{~s}$ each time and then left at room temperature for $30 \mathrm{~min}$. Cell extracts were then centrifuged at $5000 \mathrm{~g}$ for $10 \mathrm{~min}$. The supernatant was collected and, prior to their fractionation by OFFGEL ${ }^{\mathrm{T}}, 4$ times their volume of ice cold acetone was added. Samples were kept at $-20{ }^{\circ} \mathrm{C}$ for $1 \mathrm{~h}$ and were 
then centrifuged at $5000 \mathrm{~g}$ for $10 \mathrm{~min}$. The pellet was air dried at room temperature and was kept at $-20{ }^{\circ} \mathrm{C}$ for further analysis.

The OffGEL ${ }^{\mathrm{m}}$ system (Agilent 3100 OFFGEL $^{\mathrm{ma}}$ fractionator, Agilent Technologies) utilises a 12-well chamber in which is placed on an immobilized $\mathrm{pH}$ gradient gel. The protein solution is introduced into the open top of each of the chambers. An electric field is applied through the chamber which facilitates the migration of charged proteins out of the chamber, into the gel, and from one well to another until they reach the well where the $\mathrm{pH}$ of the gel is equal to the $\mathrm{pI}$ of the protein. The proteins can be then recovered in solution, acetone precipitated and used for further analysis by tandem mass spectrometry, as described below.

The acetone precipitated cell pellets destined for OFFGEL $^{\mathrm{Tm}}$ fractionation were dissolved in sample buffer $(7 \mathrm{M}$ Urea, $2 \mathrm{M}$ thiourea 1\% DTT, 10\% glycerol (all from Sigma-UK) and 1.0\% ( $v / \mathrm{v})$ IPG buffer $\mathrm{pH}$ 3-10 (GE Healthcare, UK)). Protein concentrations in all samples were measured using a 2-D Quant Kit (Amersham Biosciences, UK) with a standard curve using Bovine serum albumin (BSA). For each sample, $150 \mu \mathrm{l}(170 \mu \mathrm{g})$ was loaded into each of the twelve wells on the OFFGEL ${ }^{\mathrm{mm}}$ fractionator. Fractionation was carried out using a program optimized to focus samples for about $24 \mathrm{~h}$ over which the voltage was gradually increased from $500 \mathrm{~V}$ to $1000 \mathrm{~V}$ before a final limiting voltage of $8000 \mathrm{~V}$ was applied. A maximum current of $50 \mu \mathrm{A}$ was applied throughout the focussing stage and the temperature was stabilised to $22{ }^{\circ} \mathrm{C}$ during the fractionation. The protein fractions were recovered from each well at the end of run. About $30 \mu \mathrm{l}$ of the sample (20\% of the total) recovered from each OFFGEL ${ }^{\mathrm{mi}}$ fraction was placed in a separate tube for analysis by SDS-PAGE gel electrophoresis and the rest was utilised for liquid chromatography tandem MS analysis experiments. The two samples obtained from each fraction were then acetone precipitated separately. The procedure was as described above, but the samples were first diluted with two volumes of distilled water before addition of the acetone.

The efficiency of the OFFGEL ${ }^{\mathrm{Tw}}$ separation was monitored using 1D electrophoretic analysis. To this end, the acetone precipitates derived from the smaller samples recovered from each fraction were reconstituted in $20 \mu \mathrm{l}$ of loading buffer (100 mM Tris pH 6.8, 4\% SDS, 20\% glycerol, $1 \% v / \mathrm{v}$ $\beta$-mercaptoethanol and $0.1 \%$ bromophenol blue). The samples and molecular weight marker (PageRuler ${ }^{\mathrm{mw}}$, Fermentas, UK) were heated at $100{ }^{\circ} \mathrm{C}$ for $10 \mathrm{~min}$ and then applied to a $10 \%$ resolving gel (using the Bio-Rad Protean II XL system) for protein electrophoresis. The gels were run at $50 \mathrm{~V}$ through the stacking gel and $150 \mathrm{~V}$ through the resolving gel. Proteins were stained using 0.5\% Coomassie Brilliant Blue G250 (Sigma, UK), 40\% ethanol and 10\% acetic acid for $1 \mathrm{~h}$, and destained in 20\% ethanol and 10\% acetic acid for $2 \mathrm{~h}$.

To digest the proteins and isolate the resulting tryptic peptides generated from OFFGEL ${ }^{\mathrm{mm}}$ fractionation, the larger of the acetone precipitated pellets obtained from each OFFGEL $^{\text {Tx }}$ fraction were reconstituted in $150 \mu \mathrm{l}$ of $1 \mathrm{X}$ digestion buffer containing $1 \mathrm{M}$ ammonium bicarbonate, $1 \mathrm{M} \mathrm{CaCl} 2$ and $1.2 \mathrm{~g}$ urea (all from Sigma, UK). The samples were then placed in a $10 \mathrm{kDa}$ filter (Ambion $0.5 \mathrm{ml}$, 10,000 MW cut- off centrifugal filter, Millipore UK Limited, UK) and centrifuged at $14000 \mathrm{~g}$ for $15 \mathrm{~min}$. The filtrate was removed from the filter holder and $2.5 \mu \mathrm{l}$ of $10 \mathrm{mM}$ DTT was added to the filter. The tubes were incubated at $37{ }^{\circ} \mathrm{C}$ for $20 \mathrm{~min}$ and $2 \mu \mathrm{l}$ of $30 \mathrm{mM}$ iodoacetamide (Sigma-UK) was then added to the filter. The tubes were incubated at room temperature for $20 \mathrm{~min}$. At this point $200 \mu \mathrm{l}$ of $1 \mathrm{X}$ digestion buffer was added to the tubes which were centrifuged at $14000 \mathrm{~g}$ for $15 \mathrm{~min}$. The filtrate was removed from the filter holder and $5 \mu \mathrm{l}$ of $0.1 \mu \mathrm{g} / \mu \mathrm{l}$ of trypsin (Roche Diagnostics, UK) was added to the filters. The tubes were then incubated at $37^{\circ} \mathrm{C}$ overnight. To stop the reaction, $1 \mu \mathrm{l}$ of formic acid and $200 \mu \mathrm{l}$ of $50 \mathrm{mM}$ ammonium bicarbonate were then added to the filters. The tubes were then centrifuged at $14000 \mathrm{~g}$ for $15 \mathrm{~min}$. The filtrate was retained and vacuum centrifuged until all solution was removed. The dried pellets were reconstituted in $40 \mu \mathrm{l}$ of buffer A, containing $0.1 \%$ formic acid and $10 \%$ acetonitrile (all from Sigma, UK), and kept at $4{ }^{\circ} \mathrm{C}$ for further analysis.

For the label free mass spectrometric quantitative analysis of the samples, $7.5 \mu \mathrm{l}$ of the tryptic digest from each fraction was mixed with $5 \mu \mathrm{l}$ of the rabbit glycogen phosphorylase B standard tryptic digest at 50 femtomoles $\mu \mathrm{L}^{-1}$, (Waters, UK). A $2.5 \mu \mathrm{L}$ aliquot of the mixture of sample and standard digests was then injected three times into the mass spectrometer. HPLC separation of tryptic peptides was carried out using a Waters nanoACQUITY $^{\mathrm{Tm}}$ UPLC fitted with a Symmetry $^{\circ}$ C18 HPLC trapping column of $20 \mathrm{~mm}$ length and an internal diameter (ID) of $180 \mu \mathrm{m}$ (Waters, Ltd). Sample loading time was $1 \mathrm{~min}$ at a flow rate of $15 \mu \mathrm{min}^{-1}$ in $97 \%$ water, $3 \%$ acetonitrile. The trapped peptides were then eluted on to a BEH130 C18 HPLC analytical column of $25 \mathrm{~cm}$ length and an ID of $75 \mu \mathrm{m}$ with an elution gradient of $3-40 \%$ acetonitrile in water (containing a constant $0.1 \%$ formic acid) running for $30 \mathrm{~min}$ at a flow rate of $300 \mathrm{nmin}^{-1}$. The column temperature was maintained at $35{ }^{\circ} \mathrm{C}$ and peptides were eluted via a $10 \mu \mathrm{m}$ PicoTip emitter (New Objective). into the nano-ESI source of a Waters Synapt G1 High Definition instrument controlled using MassLynx v4.1 (Waters Ltd.). Immediately before analysis, the mass spectrometer was calibrated using the product ion spectrum of glu-fibrinopeptide B $(500 \mathrm{fmol}$ $\mathrm{Hl}^{-1}$ of peptide in $50 \%$ water, $50 \%$ acetonitrile containing $0.1 \%$ formic acid). The instrument was operated in V mode 
using data independent $\left(\mathrm{MS}^{\mathrm{E}}\right)$ acquisition. The low energy, survey, scan was performed between $\mathrm{m} / z$ 50-2000 with a trap cell collision energy of $6 \mathrm{eV}$. The elevated energy, product ion, scan was acquired similarly except that the trap collision energy was ramped from 15 to $40 \mathrm{eV}$ during data acquisition. Transfer cell collision energy was $4 \mathrm{eV}$ for both scans and the lock mass was recorded every $30 \mathrm{~s}$. After data-independent acquisition, protein identification was carried out using the UniProt/Swiss-Prot database (Release 2012_04) and a search algorithm embedded within the ProteinLynx Global Server software package, (version 2.4, Waters Ltd.) which was specifically developed for the qualitative identification of proteins over a wide dynamic range in complex biological samples [48]. The following settings were applied; automatic settings for precursor and product ion mass tolerance; minimum fragment ion matches per peptide, 8; minimum fragment ion matches per protein, 15; minimum peptide matches per protein, 1 ; fixed modification, carbamidomethyl Cys; variable modification, oxidised Met; number of missed cleavages, 1; false positive rate, $1 \%$.

\section{Protein quantification strategy}

Proteins were quantitated using a HI3 label-free approach that compares the intensity of the precursor ions identified from sample proteins with those derived from a standard present at known concentration [49]. The algorithm used, also embedded within the ProtynLynx Global Sever software package, integrates the volume of each extracted ion (charge state reduced, deisotoped and mass corrected) across the mass chromatogram. Protein concentrations are estimated by comparison of the average intensity of the three most abundant peptides, from a particular protein released from the chromatography columns, with the equivalent value determined for a known amount of the internal standard (a tryptic digest of rabbit phosphorylase B) introduced to the experimental samples before analysis. Each of the 12 OFFGEL $^{\mathrm{mm}}$ fractions derived from a given sample were analysed separately and the data were then combined to give the total amount of a given protein present in that sample. Each experiment was conducted on three separate occasions and each of these biological replicates was analysed three times. Changes in expression levels were only considered for those proteins detected and quantitated in a minimum of two of the three biological replicates.

\section{Quantitative real time PCR}

RNA was extracted from 70 to $80 \%$ confluent T75 flasks (about $10^{7}$ cells) of untreated and $5 \mu \mathrm{M}$ IAPP treated Rin-5F cells using an RNeasy kit (Qiagen, West Sussex, UK) according to the manufacturer's instructions. The RNA concentration and purity were measured using an Agilent 2100 Bioanalyser. The RNA purity was measured from the A260nm/A280nm ratio and was always in the range of 1.9 to 2.0. RNA was normalized for all the cell samples to $8.5 \mu \mathrm{g}$ for the cDNA synthesis and reverse transcribed using qScript $^{\circ}$ cDNA SuperMix (Quanta Biosciences, Gaithersburg, MD, U.S.A) according to the manufacturer's instructions. Quantitative real time PCR was performed using the Light-Cycler 480 II platform (Roche Diagnostics, UK). The PCR was performed in $10 \mu \mathrm{l}$ of reaction volume with $5 \mu \mathrm{l}$ of qPCR MasterMix Plus for SYBR $^{\circ}$ Green, $4 \mu$ of $10 \mathrm{x}$ diluted cDNA and $0.1 \mu \mathrm{l}$ of each forward and reverse primer at the stock concentration of $20 \mu \mathrm{M}$. The mixtures were then loaded in a 384 well plate. The plates were sealed with Microseal 'B' film (Bio-Rad, UK) and centrifuged at $800 \mathrm{~g}$ for $1 \mathrm{~min}$. The PCR conditions were: activation of enzymes at $95{ }^{\circ} \mathrm{C}$ for $10 \mathrm{~min}, 40$ cycles of denaturation at $95{ }^{\circ} \mathrm{C}$ for $15 \mathrm{~s}$, annealing and extension at $60 \mathrm{C}$ for $1 \mathrm{~min}$.

\section{In cell Western analysis}

The cells were initially plated in triplicate at a density of $2.5 \times 10^{4}$ cells/well in 96 well plates. For the treated samples, hIAPP was added to the cells to final concentrations of $5 \mu \mathrm{M}$ per well. Plates were incubated for $24 \mathrm{~h}$ at $37^{\circ} \mathrm{C}$. The In Cell Western assay was then carried out using In-Cell Western ${ }^{\mathrm{mm}}$ Kit II (LI-COR Biosciences, UK) according to the manufacturer's instructions. Primary antibodies for this assay were used as follows: Anti-PCNA antibody, 1:100; Anti-EEF2 antibody, 1:120; Anti-Superoxide Dismutase 1 antibody, 1:200; Anti-Peroxiredoxin1 antibody, 1:250; Anti-ERp57 antibody,1:500; Anti-14-3-3 zeta antibody 1:500 (all Abcam-UK). Donkey anti-rabbit-IRDye 700CW (LI-COR Biosciences, UK) secondary antibody was diluted 500-fold and used for the detection of the primary antibodies. The Odyssey Infrared Imaging System (LI-COR Biosciences, UK) was then used to scan the plate and to detect the signal from the secondary antibody in the $800 \mathrm{~nm}$ channel.

\section{Data analysis}

KEGG pathways and GO gene ontology research tool annotations of the identified proteins were obtained using the DAVID Web-based tool [39]. Protein-protein interactions were determined by querying each of the proteins detected and quantitated in a minimum of two replicates using the STRING database [40]. The data obtained from the STRING database were imported into the Cytoscape software to construct a network of protein-protein interactions [41]. The NetworkAnalyzer Cytoscape plugin was used to analyse the interaction network including degree [50], closeness centrality [42] and betweenness centrality [51]. The MIPS database [45] was used to investigate the protein complexes that contain the identified proteins.

Numerical data were subject to statistical analysis using standard deviation and Student's t-test. 


\section{Additional files}

Additional file 1: Figure S1. SDS-PAGE analysis of the OFFGELTM fractions of untreated and IAPP treated Rin-5F cells. (DOCX 846 kb)

Additional file 2: Table S1. Protein Mass Spectrometry Data. (ZIP 2439 kb) Additional file 3: Table S2. Protein Mass Spectrometry Data Table Descriptors. (DOCX $12 \mathrm{~kb}$ )

Additional file 4: Table S3. Protein-Protein Interactions. (XLSX 44 kb)

Additional file 5: Figure S2. Protein-Protein Interaction Network; Up-regulated proteins are colour coded by red, down-regulated by green and unchanged by yellow. (TIF $877 \mathrm{~kb}$ )

\section{Abbreviations}

BSA: Bovine serum albumin; CHAPS: 3-[(3-Cholamidopropyl)dimethylammonio]-1propanesulfonate; DMSO: Dimethylsulphoxide; DTT: Dithiothreitol; EDTA: 2,2',2",2"'(Ethane-1,2-diyldinitrilo)tetraacetic acid; EGTA: Ethylene glycol-bis(2-aminoethylether)$N, N, N^{\prime}, N^{\prime}$-tetraacetic acid; ER: Endoplasmic reticulum; GO: Gene ontology; HFIP: 1,1,1,3,3,3-Hexafluoroisopropanol; hIAPP: Human islet amyloid polypeptide; IAPP: Islet amyloid polypeptide; IPG: Immobilized pH gradient; LC: Liquid chromatography; MS: Mass spectrometry; MTT: 3-(4,5-Dimethylthiazol-2-yl)-2,5diphenyltetrazolium bromide; NIDDM: Non-insulin-dependent diabetes mellitus; PCR: Polymerase chain reaction; T2D: Type 2 diabetes; TCA: Tricarboxylic acid UBE2E2: Ubiquitin-conjugating enzyme E2E2

\section{Acknowledgments}

Not applicable.

\section{Funding}

We thank the Biotechnology and Biological Sciences Research Council (BBSRC), and Engineering and Physical Sciences Research Council for their funding of the Manchester Centre for Integrative Systems Biology (grant BB/C008219/1). The funding body had no input into the design of the study and collection, analysis, and interpretation of data and in writing the manuscript.

\section{Availability of data and materials}

All data generated or analysed during this study are included in this published article and its supplementary information files.

\section{Authors' contributions}

SMN performed the experimental work. PFGS and AJD designed the experiments. SMN, JMS, PFGS and AJD analysed the data. All authors read and approved the final manuscript.

\section{Ethics approval and consent to participate}

Not applicable.

\section{Consent for publication}

Not applicable.

\section{Competing interests}

Andrew Doig is an Editorial Board Member of BMC Biochemistry. The authors declare that they have no competing interests

\section{Publisher's Note}

Springer Nature remains neutral with regard to jurisdictional claims in published maps and institutional affiliations.

\section{Author details}

'Manchester Institute of Biotechnology, The University of Manchester, 131 Princess Street, Manchester M1 7DN, UK. ²Division of Evolution \& Genomic Sciences, Faculty of Biology, Medicine and Health, The University of Manchester, Manchester M13 9PT, UK. ${ }^{3}$ Division of Neuroscience and Experimental Psychology, School of Biological Sciences, Faculty of Biology, Medicine and Health, The University of Manchester, Manchester M13 9PT, UK.
Received: 18 April 2018 Accepted: 22 October 2018

Published online: 12 November 2018

\section{References}

1. Uusitupa M, Tuomilehto J, Puska P. Are we really active in the prevention of obesity and type 2 diabetes at the community level? Nutr Metab Cardiol Cardiovasc Dis. 2011:21(5):380-9.

2. Porte D. $\beta$-Cells in type-Il diabetes-mellitus. Diabetes. 1991;40(2):166-80.

3. Boada CAC, Martinez-Moreno JM. Pathophysiology of diabetes mellitus type 2: beyond the duo "insulin resistance-secretion deficit". Nutricion Hospitalaria. 2013:28:78-87.

4. Pillay K, Govender P. Amylin uncovered: a review on the polypeptide responsible for type II diabetes. Biomed Res Int. 2013;17:826706.

5. Westermark P, Andersson A, Westermark GT. Islet amyloid polypeptide, islet amyloid, and diabetes mellitus. Phys Rev. 2011;91(3):795-826.

6. Clark A, Lewis CE, WIllis AC, Cooper GJS, Morris JF, Reid KBM, Turner RC. Islet amyloid formed from diabetes-associated peptide may be pathogenic in type II diabetes. Lancet. 1987;2(8553):231-4.

7. O'Brien TD, Butler PC, Westermark P, Johnson KH. Islet amyloid polypeptide - a review of its biology and potential roles in the pathogenesis of diabetesmellitus. Vet Pathol. 1993;30(4):317-32.

8. Clark A, Jones LC, de Koning E, Hansen BC, Matthews DR. Decreased insulin secretion in type 2 diabetes: a problem of cellular mass or function? Diabetes. 2001;50:S169-71.

9. Jurgens CA, Toukatly MN, Fligner CL, Udayasankar J, Subramanian SL, Zraika S, Aston-Mourney K, Carr DB, Westermark P, Westermark GT, et al. $\beta$-Cell loss and $\beta$-cell apoptosis in human type 2 diabetes are related to islet amyloid deposition. Am J Pathol. 2011:178(6):2632-40.

10. Lorenzo A, Razzaboni B, Weir GC, Yankner BA. Pancreatic islet cell toxicity of amylin associated with type-2 diabetes mellitus. Nature. 1994;368:756-60.

11. Brunner $Y$, Coute $Y$, lezzi M, Foti M, Fukuda M, Hochstrasser DF, Wollheim CB, Sanchez J-C. Proteomics analysis of insulin secretory granules. Mol Cell Proteomics. 2007:6:1007-17.

12. Rao PV, Reddy AP, Lu X, Dasari S, Krishnaprasad A, Biggs E, Roberts CT, Nagalla SR. Proteomic identification of salivary biomarkers of type-2 diabetes. J Proteome Res. 2009;8(1):239-45.

13. Hwang $H$, Bowen BP, Lefort N, Flynn CR, De Filippis EA, Roberts C, Smoke CC, Meyer C, Hojlund K, Yi ZP, et al. Proteomics analysis of human skeletal muscle reveals novel abnormalities in obesity and type 2 diabetes. Diabetes. 2010;59(1):33-42.

14. Hung PH, Lu YC, Chen YW, Chou HC, Lyu PC. Proteomic identification of plasma signatures in type 2 diabetic nephropathy. J Integrated Omics. 2011; 1:151-6.

15. Ly A, Scheerer MF, Zukunft S, Muschet C, Merl J, Adamski J, de Angelis MH, Neschen S, Hauck SM, Ueffing M. Retinal proteome alterations in a mouse model of type 2 diabetes. Diabetologia. 2013;57(1):192-203.

16. Li RX, Chen HB, Tu K, Zhao SL, Zhou H, Li SJ, Dai J, Li QR, Nie S, Li YX, et al. Localized statistical quantification of human serum proteome associated with type 2 diabetes. PLoS One. 2008;3(0):e3224.

17. Waanders LF, Chwalek K, Monetti M, Kumar C, Lammert E, Mann M. Quantitative proteomic analysis of single pancreatic islets. Proc Natl Acad Sci U S A. 2009;106(45):18902-7.

18. Petyuk VA, Qian WJ, Hinault C, Gritsenko MA, Singhal M, Monroe ME, Camp DG, Kulkarni RN, Smith RD. Characterization of the mouse pancreatic islet proteome and comparative analysis with other mouse tissues. J Proteome Res. 2008;7(8):3114-26.

19. Hickey AJR, Bradley JWI, Skea GL, Middleditch MJ, Buchanan CM, Phillips ARJ, Cooper GJS. Proteins associated with immunopurified granules from a model pancreatic islet $\beta$-cell system: proteomic snapshot of an endocrine secretory granule. J Proteome Res. 2009;8(1):178-86.

20. Schvartz D, Brunner Y, Coute Y, Foti M, Wollheim CB, Sanchez JC. Improved characterization of the insulin secretory granule proteomes. J Proteome. 2012:75(15):4620-31.

21. Lim Y-A, Rhein V, Baysang G, Meier F, Poljak A, Raftery MJ, Guilhaus M, Ittner LM, Eckert A, Götz J. A $\beta$ and human amylin share a common toxicity pathway via mitochondrial dysfunction. Proteomics. 2010;10:1621-33.

22. O'Cualain RDM, Hyde JE, Sims PFG. A protein-centric approach for the identification of folate enzymes from the malarial parasite, plasmodium falciparum, using OFFGEL (TM) solution-based isoelectric focussing and mass spectrometry. Malar J. 2010;9:286-97. 
23. Trikha S, Jeremic AM. Distinct internalization pathways of human amylin monomers and its cytotoxic oligomers in pancreatic cells. PLoS One. 2013; 8(9):18.

24. Peinado JR, Sami F, Rajpurohit N, Lindberg I. Blockade of islet amyloid polypeptide fibrillation and cytotoxicity by the secretory chaperones 7B2 and proSAAS. FEBS Lett. 2013:587(21):3406-11.

25. Konarkowska B, Aitken JF, Kistler J, Zhang S, Cooper GJS. The aggregation potential of human amylin determines its cytotoxicity towards islet $\beta$-cells. FEBS J. 2006;273:3614-24.

26. Zhang S, Liua J, Saafi EL, Cooper GJS. Induction of apoptosis by human amylin in RINm5F islet L-cells is associated with enhanced expression of p53 and p21 WAF1/CIP1. FEBS Lett. 1999:455:315-20.

27. Saafi EL, Konarkowska B, Zhang SP, Kistler J, Cooper GJS. Ultrastructural evidence that apoptosis is the mechanism by which human amylin evokes death in RINm5F pancreatic islet beta-cells. Cell Biol Int. 2001;25(4):339-50.

28. Lo CS, Chang SY, Chenier I, Filep JG, Ingelfinger JR, Zhang SL, Chan JSD. Heterogeneous nuclear ribonucleoprotein $\mathrm{F}$ suppresses angiotensinogen gene expression and attenuates hypertension and kidney injury in diabetic mice. Diabetes. 2012;61(10):2597-608

29. Somjen D, Shen M, Stern N, Mirsky N. Diabetes modulates differentially creatine kinase-specific activity responsiveness to estradiol-17 beta and to raloxifene in rat organs. J Cell Biochem. 2006;99(1):133-9.

30. Giacco F, Brownlee M. Oxidative stress and diabetic complications. CircRes. 2010;107(9):1058-70.

31. Thandavarayan RA, Watanabe K, Ma M, Veeyaveedu PT, Gurusamy N, Palaniyandi SS, Zhang S, Muslin AJ, Kodama M, Aizawa Y. 14-3-3 protein regulates Ask1 signaling and protects against diabetic cardiomyopathy. Biochem Pharmacol. 2008;75(9):1797-806.

32. Garamvolgyi Z, Prohaszka Z, Rigo J, Kecskemeti A, Molvarec A. Increased circulating heat shock protein 70 (HSPA1A) levels in gestational diabetes mellitus: a pilot study. Cell Stress Chaperones. 2015;20(4):575-81.

33. Kowluru A, Matti A. Hyperactivation of protein phosphatase $2 A$ in models of glucolipotoxicity and diabetes: potential mechanisms and functional consequences. Biochem Pharmacol. 2012;84(5):591-7.

34. Andreeva AV, Kutuzov MA, Voyno-Yasenetskaya TA. A ubiquitous membrane fusion protein alpha SNAP: a potential therapeutic target for cancer, diabetes and neurological disorders? Expert Opin Ther Targets. 2006;10(5):723-33.

35. Salama M, Tsuji M, Tamura M, Kagawa S. Impact of aging and diabetes mellitus on the expression of the proliferating cell nuclear antigen in rat testicular tissue. Arch Androl. 1998:40(2):95-107.

36. Kazakova EV, Wuo YH, Zhou ZY, Chen MJ, Wang TT, Tong HX, Zhuang TW, Sun $\mathrm{LL}$, Qiao H. Association between UBE2E2 variant rs7612463 and type 2 diabetes mellitus in a Chinese Han population. Acta Biochim Pol. 2015;62(2):241-5.

37. Guay C, Joly E, Pepin E, Barbeau A, Hentsch L, Pineda M, Madiraju SRM, Brunengraber $\mathrm{H}$, Prentki M. A role for cytosolic Isocitrate dehydrogenase as a negative regulator of glucose signaling for insulin secretion in pancreatic beta-cells. PLoS One. 2013:8(10):e77097.

38. Baseler WA, Thapa D, Jagannathan R, Dabkowski ER, Croston TL, Hollander JM. miR-141 as a regulator of the mitochondrial phosphate carrier (Slc25a3) in the type 1 diabetic heart. Am J Physiol-Cell Physiol. 2012;303(12):C1244-51.

39. Huang W, Sherman BT, Tan Q, Kir J, Liu D, Bryant D, Guo Y, Stephens R, Baseler MW, Lane HC, et al. DAVID bioinformatics resources: expanded annotation database and novel algorithms to better extract biology from large gene lists. Nucleic Acids Res. 2007;35:169-75.

40. von Mering C, Jensen LJ, Snel B, Hooper SD, Krupp M, Foglierini M, Jouffre N, Huynen MA. P. B: STRING: known and predicted protein-protein associations, integrated and transferred across organisms. Nucleic Acids Res. 2005;33:433-7.

41. Shannon P, Markiel A, Ozier O, Baliga NS, Wang JT, Ramage D, Amin N, Schwikowski B, Ideker T. Cytoscape: a software environment for integrated models of biomolecular interaction networks. Genome Res. 2003;13(11): 2498-504.

42. Newman MEJ. A measure of betweenness centrality based on random walks. Soc Networks. 2005:27:39-54

43. Gandhi TK, Zhong J, Mathivanan S, Karthick L, Chandrika KN, Mohan SS, Sharma S, Pinkert S, Nagaraju S, Periaswamy B, et al. Analysis of the human protein interactome and comparison with yeast, worm and fly interaction datasets. Nat Genet. 2006:38:285-93.

44. Goh K-I, Cusick ME, Valle D, Childs B, Vidal M, Barabási A-L. The human disease network. Proc Natl Acad Sci U S A. 2007:104:8685-90.
45. Pagel P, Kovac S, Oesterheld M. Brauner BD-K, I., Frishman G, Montrone C, mark P, Stümpflen V, Mewes HW, Ruepp a et al: the MIPS mammalian protein-protein interaction database. Bioinformatics. 2005;21:832-4.

46. Casas S, Gomis R, Gribble FM, Altirriba J, Knuutila S, Novials A. Impairment of the ubiquitin-proteasome pathway is a downstream endoplasmic reticulum stress response induced by extracellular human islet amyloid polypeptide and contributes to pancreatic $\beta$-cell apoptosis. Diabetes. 2007;56:2284-94.

47. Shearman MS, Ragan Cl, Iversen LL. Inhibition of PC12 cell redox activity is a specific, early indicator of the mechanism of $\beta$-amyloid mediated cell death. Proc Natl Acad Sci U S A. 1994;91:1470-4.

48. Li GZ, Vissers JPC, Silva JC, Golick D, Gorenstein MV, Geromanos SJ. Database searching and accounting of multiplexed precursor and product ion spectra from the data independent analysis of simple and complex peptide mixtures. Proteomics. 2009;9(6):1696-719.

49. Silva JC, Gorenstein MV, Li GZ, Vissers JPC, Geromanos SJ. Absolute quantification of proteins by LCMSE - a virtue of parallel MS acquisition. Mol Cell Proteomics. 2006;5:144-56.

50. Diestel R. Graph theory. Heidelberg: Springer-Verlag; 2005.

51. Altshuler Y, Puzis R, Elovici Y, Bekhor S, Pentland A. Augmented betweenness centrality for mobility prediction in transportation networks. In: International Workshop on Finding Patterns of Human Behaviors in Network and Mobility Data. Athens: NEMO; 2011.

\section{Ready to submit your research? Choose BMC and benefit from:}

- fast, convenient online submission

- thorough peer review by experienced researchers in your field

- rapid publication on acceptance

- support for research data, including large and complex data types

- gold Open Access which fosters wider collaboration and increased citations

- maximum visibility for your research: over $100 \mathrm{M}$ website views per year

At $\mathrm{BMC}$, research is always in progress.

Learn more biomedcentral.com/submissions 